\title{
TINJAUAN YURIDIS SIARAN PERTELEVISIAN YANG MENYEBABKAN ANAK MELAKUKAN KEJAHATAN BERDASARKAN UNDANG-UNDANG NOMOR 32 TAHUN 2002 TENTANG PENYIARAN
}

\author{
Oleh : \\ Herald Diego * \\ Ibrahim * \\ Ruslan Abdul Gani *
}

\begin{abstract}
ABSTRAK
Norma hukum tentang penayangan siaran pertelevisian yang dapat menyebabkan terjadinya kriminalitas anak, dapat dirujuk pada Pasal 57 Undang-Undang Penyiaran. Norma ketentuan pidana tersebut tidak dapat dijadikan sarana hukum yang efektif untuk menangkal munculnya tayangan televisi yang berdampak pada lahirnya kriminalitas anak, karena perumusannya mengandung sejumlah kelemahan. Kelemahan yang ditemui menimbulkan ketidak-adilan serta berkontribusi secara nyata terhadap pelemahan penegakan hukum terhadap tindak-tindak pidana penyiaran. Norma kebijakan hukum pidana yang sebaiknya dinormakan terhadap pelaku tindak pidana pelanggaran isi siaran, di dalam Undang-Undang Penyiaran di masa depan adalah norma yang memuat kejelasan dan ketegasan unsur-unsur tindak pidana penyiaran, pembebanan pertanggungjawaban pidana terhadap korporasi yang menjadi pemilik stasiun televisi yang menayangkan siaran yang berpotensi menimbulkan kriminalitas anak, dan norma sanksi pidana minimal di samping pidana maksimal yang telah berlaku saat ini.
\end{abstract}

Kata Kunci: Siaran Pertelevisian, Anak Pelaku Kejahatan,

\section{A. Latar Belakang Masalah}

Masyarakat wajib dilindungi dari kejahatan, sehingga diperlukan sebuah kebijakan hukum pidana. Kebijakan hukum pidana yang dimaksud adalah usaha untuk mewujudkan peraturan perundang-undangan pidana yang baik, yang sesuai dengan keadaan dan situasi, pada suatu waktu dan masa-masa yang akan datang, serta yang dikehendaki dan diperkirakan bisa digunakan untuk mengeksperesikan yang terkandung dalam masyarakat, dan untuk mencapai apa yang dicita-citakan. Kebijakan hukum pidana dapat dipandang sebagai upaya untuk menciptakan perubahan tatanan hukum di tengah masyarakat, yang mampu meminimalisir terjadinya berbagai bentuk kejahatan, baik berupa kejahatan baru, maupun kejahatan lama dengan modus-modus yang baru.

\footnotetext{
* PNS di Pemda Provinsi Jambi, Alumni Program Magister Ilmu Hukum Unbari.

* Pengajar Program Magister Ilmu Hukum Unbari.

* Pengajar Program Magister Ilmu Hukum Unbari.
} 
Salah satu faktor yang dapat memicu atau merangsang seseorang melakukan kejahatan, adalah karena faktor tontonan yang anti sosial, tidak mendidik dan menonjolkan kekerasan, pornografi dan pornoaksi di media elektronik, terutama televisi. Terkait dengan dampak negatif dari tayangan televisi, Litlejohn Stephen W \& Foss, Karen A., yang menguraikan bahwa:

Efek tayangan yang disiarkan ditelevisi akan mempengaruhi persepsi penontonnya. Salah satunya adalah efek tayangan yang memuat kekerasan akan dapat menimbulkan efek-efek sebagai berikut:

1. Catharsis: tayangan kekerasan di media massa dapat digunakan sebagai mekanisme katarsis bagi penonton untuk melampiaskan fantasinya tentang kekerasan sehingga dapat mengurangi perilaku kekerasan yang ada

2. Social learning: tayangan kekerasan dapat dijadikan sebagai model belajar bagi penonton.

3. Priming: ketika tayangan kekerasan berlangsung terus menerus dan ditonjolkan, dapat memberikan dampak jangka panjang pada penonton.

4. Arousal: membangkitkan perilaku kekerasan dalam diri penonton

5. Desensitization: menjadikan penonton tidak lagi sensitif atau peka terhadap perilaku kekerasan, lama-lama dianggap sebagai hal yang biasa.

6. Fear: menimbulkan dampak ketakutan. ${ }^{1}$

Sejalan dengan pendapat di atas, Tim Pakar Yayasan Jati Diri Bangsa mengemukakan bahwa "Dalam era kemajuan teknologi informasi dan telekomunikasi saat ini, salah satu faktor yang berpengaruh sangat besar dalam pembangunan, atau sebaliknya pengrusakan karakter masyarakat atau bangsa adalah media massa, khususnya media elektronik dengan pelaku utama adalah televisi. ${ }^{2}$

Masih terkait dengan dampak buruk televisi terhadap karakter bangsa, Muhammad Iksan berpandangan sebagai berikut:

Media massa sekarang memakai teknologi yang makin lama makin canggih. Namun tanpa kecerdasan dan kearifan, media massa yang didukung teknologi canggih tersebut justru akan melemahkan atau merusak karakter bangsa. Saya

\footnotetext{
${ }^{1}$ Littlejohn,Stephen W. \& Foss, Karen A., Theories of Human Communication, $8^{\text {th }}$ edition, Thomson Wadsworth, USA, 2005, hal. 43.

${ }^{2}$ Tim Pakar Jati Diri Bangsa, Pendidikan Karakter di Sekolah, Dari Gagasan ke Tindakan, Elex Media Komputindo, Jakarta, 2011, hal. 45.
} 
tidak ragu mengatakan, media elektronik di Indonesia, khususnya televisi, sekarang ini kontribusinya 'nihil' dalam pembangunan karakter bangsa. Saya tidak bermaksud untuk mengatakan bahwa tidak ada program televisi yang baik. Namun sebagian besar program televisi justru lebih menonjolkan karakter buruk daripada karakter baik. Sering kali pengaruh lingkungan keluarga yang baik justru dirusak oleh siaran media televisi. Di keluarga, anak-anak dididik untuk menghindari kekerasan, namun acara TV justru penuh dengan adegan kekerasan. Di rumah, anak-anak dididik untuk hidup sederhana, namun acara sinetron di tevisi Indonesia justru memamerkan kemewahan. Di rumah anakanak dididik untuk hidup jujur, namun tayangan di televisi Indonesia justru secara tidak langsung menunjukkan 'kepahlawanan' tokoh-tokoh yang justru di mata publik di anggap 'kaisar' atau 'pangeran-pangeran' koruptor. Para guru agama mengajarkan bahwa membicarakan keburukan orang lain dan bergosip itu tidak baik, namun acara televisi, khususnya infotainment, penuh dengan gosip. Bapak dan ibu guru di sekolah mendidik para murid untuk berperilaku santun, namun suasana sekolah di sinetron Indonesia banyak menonjolkan perilaku yang justru tidak santun dan melecehkan guru. Secara umum, banyak tayangan di televisi Indonesia, justru 'membongkar' anjuran berperilaku baik yang ditanamkan di di rumah oleh orang tua dan oleh para guru di sekolah. ${ }^{3}$

Kemudian, menurut hasil penelitian American Psychological Asociation (APA) pada tahun 1995 terungkap bahwa tayangan yang bermutu akan mempengaruhi seseorang untuk berperilaku baik. Adapun tayangan yang kurang bermutu akan memengaruhi seseorang untuk berperilaku buruk. Bahkan, penelitian ini menyimpulkan bahwa hampir semua perilaku buruk yang dilakukan orang adalah hasil pelajaran yang mereka terima dari media semenjak usia anak-anak. ${ }^{4}$

Berdasarkan pendapat para ahli di atas, dapat dilihat dengan jelas betapa besarnya pengaruh tayangan televisi terhadap pembentukan karakter, terutama karakter anak. Tayangan yang bersifat anti sosial dan tidak mendidik, telah meluluh-lantakkan

\footnotetext{
${ }^{3}$ Muhammad Iksan, "Peran Media Massa Dalam Pembentukan Karakter", Makalah, FKIP Universitas Samawa Sumbawa Besar, 2010, hal. 3.

${ }^{4}$ Zubaedi, Desain Pendidikan Karakter: Konsepsi dan Aplikasinya dalam Lembaga Pendidikan, Kencana, Jakarta, 2011, hal. 174.
} 
penghargaan anak terhadap nilai-nilai kesopanan, kesusilaan, kedisiplinan dan etos untuk bekerja keras.

Tayangan kenakalan remaja secara berlebihan, seperti tawuran, penyalah-gunaan narkotika, geng motor dan lain sebagainya, tanpa disadari telah menjadi model pembelajaran yang demikian efektif bagi anak, untuk kemudian terdorong melakukan tindakan serupa.

Tragisnya, karena rasa ingin tahu yang demikian tinggi sebagaimana layaknya dimiliki oleh anak-anak, tayangan negatif televisi, telah menjerembabkan anak-anak, permata keluarga dan tunas harapan bangsa, ke lembah pencandu narkotika, penikmat pergaulan bebas, kesadisan geng motor, bahkan menjadi pelaku kejahatan serius seperti pencurian, perampokan, pemerkosaan, bahkan pembunuhan.

Demi mencermati deskripsi di atas, dirasakan perlunya pengaturan yang lebih tegas dan jelas tentang penyiaran, terutama penyiaran televisi, sedemikian sehingga pengaturan tersebut mampu mencegah lahirnya perilaku kriminalitas, terutama di kalangan anak-anak.

Dalam perspektif perundang-undangan Indonesia, penyelenggaraan penyiaran diatur di dalam Undang-Undang Republik Indonesia Nomor 32 Tahun 2002 tentang Penyiaran (selanjutnya disebut Undang-Undang Penyiaran).

Undang-Undang yang disahkan di Jakarta pada tanggal 28 Desember 2002, dan ditempatkan dalam Lembaran Negara Republik Indonesia Tahun 2002 Nomor 139 ini, lahir berdasarkan pertimbangan antara lain bahwa kemerdekaan menyampaikan pendapat dan memperoleh informasi melalui penyiaran sebagai perwujudan hak asasi manusia dalam kehidupan bermasyarakat, berbangsa dan bernegara, dilaksanakan secara bertanggung jawab, selaras dan seimbang antara kebebasan dan kesetaraan menggunakan hak berdasarkan Pancasila dan Undang-Undang Dasar Negara Republik Indonesia Tahun 1945.

Selanjutnya dipertimbangkan bahwa lembaga penyiaran merupakan media komunikasi massa yang mempunyai peran penting dalam kehidupan sosial, budaya, politik, dan ekonomi, memiliki kebebasan dan tanggung jawab dalam menjalankan fungsinya sebagai media informasi, pendidikan, hiburan, serta kontrol dan perekat sosial.

Kemudian dipertimbangkan pula bahwa siaran yang dipancarkan dan diterima secara bersamaan, serentak dan bebas, memiliki pengaruh yang besar dalam pembentukan pendapat, sikap, dan perilaku khalayak, maka penyelenggara penyiaran wajib bertanggung jawab dalam menjaga nilai moral, tata susila, budaya, kepribadian dan kesatuan bangsa 
yang berlandaskan kepada Ketuhanan Yang Maha Esa dan Kemanusiaan yang Adil dan Beradab.

Terkait dengan isi siaran, Undang-Undang Penyiaran mengatur secara khusus di dalam Bagian Pertama dari Bab IV mengenai Pelaksanaan Siaran, yang meliputi Pasal 35 dan Pasal 36. Di dalam Pasal 35 pada pokoknya diatur bahwa "Isi siaran harus sesuai dengan asas, tujuan, fungsi, dan arah siaran sebagaimana dimaksud dalam Pasal 2, Pasal 3, Pasal 4, dan Pasal 5".

Sementara di dalam Pasal 36 digariskan tentang detail isi siaran, yang selengkapnya menyatakan bahwa:

Pasal 36

(1) Isi siaran wajib mengandung informasi, pendidikan, hiburan, dan manfaat untuk pembentukan intelektualitas, watak, moral, kemajuan, kekuatan bangsa, menjaga persatuan dan kesatuan, serta mengamalkan nilai-nilai agama dan budaya Indonesia.

(2) Isi siaran dari jasa penyiaran televisi, yang diselenggarakan oleh Lembaga Penyiaran Swasta dan Lembaga Penyiaran Publik, wajib memuat sekurang-kurangnya $60 \%$ (enam puluh per seratus) mata acara yang berasal dari dalam negeri.

(3) Isi siaran wajib memberikan perlindungan dan pemberdayaan kepada khalayak khusus, yaitu anak-anak dan remaja, dengan menyiarkan mata acara pada waktu yang tepat, dan lembaga penyiaran wajib mencantumkan dan/atau menyebutkan klasifikasi khalayak sesuai dengan isi siaran.

(4) Isi siaran wajib dijaga netralitasnya dan tidak boleh mengu-tamakan kepentingan golongan tertentu.

(5) Isi siaran dilarang:

a. bersifat fitnah, menghasut, menyesatkan dan/atau bohong;

b. menonjolkan unsur kekerasan, cabul, perjudian, penyalah-gunaan narkotika dan obat terlarang; atau

c. mempertentangkan suku, agama, ras, dan antar golongan.

(6) Isi siaran dilarang memperolokkan, merendahkan, melecehkan dan/atau mengabaikan nilai-nilai agama, martabat manusia Indonesia, atau merusak hubungan internasional. 
Mencermati ketentuan Pasal 35 dan 36 Undang-Undang Penyiaran tersebut di atas, terlihat dengan jelas bahwa Undang-Undang Penyiaran telah mengatur dengan jelas dan tegas tentang bentuk-bentuk siaran yang dilarang untuk ditayangkan. Tayangan yang jelasjelas dilarang tersebut adalah tayangan yang bersifat fitnah, menghasut, menyesatkan dan/atau bohong, menonjolkan unsur kekerasan, cabul, perjudian, penyalah-gunaan narkotika dan obat terlarang, atau mempertentangkan suku, agama, ras, dan antar golongan, serta tayangan yang memperolokkan, merendahkan, melecehkan dan/atau mengabaikan nilai-nilai agama, martabat manusia Indonesia, atau merusak hubungan internasional.

Larangan terhadap tayangan yang anti sosial, tidak mendidik dan mendorong lahirnya kriminalitas tersebut, kemudian diperkuat dan dipertegas lagi dengan adanya ketentuan mengenai sanksi yang dapat dijatuhkan terhadap orang dan/atau lembaga penyiaran yang melanggar ketentuan tersebut. Sanksi dimaksud dapat berupa sanksi administratif dan sanksi pidana.

Bentuk-bentuk sanksi administratif yang dapat dijatuhkan kepada pelanggar isi siaran, diatur di dalam Pasal 55 ayat (2), yang pada pokoknya menggariskan bahwa sanksi administratif dapat berupa teguran tertulis; penghentian sementara mata acara yang bermasalah setelah melalui tahap tertentu; pembatasan durasi dan waktu siaran; denda administratif; pembekuan kegiatan siaran untuk waktu tertentu; tidak diberi perpanjangan izin penyelenggaraan penyiaran; atau pencabutan izin penyelenggaraan penyiaran.

Sementara itu, sanksi pidana yang dapat dijatuhkan kepada setiap orang yang melakukan pelanggaran terhadap larangan sebagaimana termaktub di dalam Pasal 36 Undang-Undang Penyiaran, digariskan di dalam Pasal 57 yang pada pokoknya menyatakan bahwa setiap orang yang melanggar ketentuan penyiaran televisi dalam Pasal 36 ayat (5) dan (6), dipidana dengan pidana penjara paling lama 5 (lima) tahun dan/atau denda paling banyak Rp. 10.000.000.000,00 (sepuluh miliar rupiah).

Merujuk pada ketentuan pidana di dalam Pasal 57 di atas, disimpulkan bahwa perbuatan menyiarkan tayangan yang bersifat fitnah, menghasut, menyesatkan dan/atau bohong, menonjolkan unsur kekerasan, cabul, perjudian, penyalah-gunaan narkotika dan obat terlarang, atau mempertentangkan suku, agama, ras, dan antar golongan, serta tayangan yang memperolokkan, merendahkan, melecehkan dan/atau mengabaikan nilainilai agama, martabat manusia Indonesia, atau merusak hubungan internasional, adalah 
perbuatan pidana, yang oleh karenanya apabila perbuatan itu dilakukan, pelakunya dapat dijatuhi pidana.

Dengan demikian, untuk mecegah penayangan siaran televisi yang tidak mendidik, anti sosial, dan merusak moral dan karakter bangsa terutama anak-anak, dan berpotensi memicu kriminalitas anak, Undang-Undang Penyiaran sesungguhnya telah menerapkan sanksi yang bersifat komprehensif, dimana pelanggar tidak hanya dapat dikenakan sanksi administratif, melainkan juga sanksi pidana, yang semestinya menimbulkan efek penjeraan (deterrence aspect).

Apabila demikian halnya, maka pertanyaan yang muncul adalah manakala larangan penayangan siaran televisi yang bersifat tidak mendidik, anti sosial dan merusak moral dan karakter anak, telah disertai dengan sanksi administratif dan sanksi pidana, mengapa tayangan yang berpotensi memicu kriminalitas anak itu, justeru semakin marak di televisitelevisi?.

Lebih jelasnya, apakah ada kelemahan di dalam perumusan sanksi yang dapat dijatuhkan kepada pelaku, sedemikian sehingga sanksi itu tidak mampu menjadi sarana hukum yang efektif untuk menghapus dan atau setidaknya mencegah penayangan yang dapat memicu terjadinya kriminalitas di kalangan anak-anak?.

Setelah dilakukan studi pendahuluan, diperoleh hipotesis awal bahwa perumusan ketentuan pidana sebagaimana termaktub di dalam Pasal 57 Undang-Undang Penyiaran, mengandung sejumlah kelemahan, yakni pertama dalam perumusan unsur-unsur tindak pidana, dan kedua dalam perumusan mengenai pertanggungjawaban pidana.

Dalam hal perumusan unsur-unsur tindak pidana, diduga ketentuan pidana Pasal 57 dimaksud terlalu bersifat umum, sedemikian sehingga tidak terdapat ukuran, kriteria dan batasan yang jelas tentang apa yang dimaksud dengan dan atau kapan sebuah tayangan dapat dikatakan sebagai tayangan yang bersifat fitnah, menghasut, menyesatkan dan/atau bohong, menonjolkan unsur kekerasan, cabul, perjudian, penyalah-gunaan narkotika dan obat terlarang, atau mempertentangkan suku, agama, ras, dan antar golongan, serta tayangan yang memperolokkan, merendahkan, melecehkan dan/atau mengabaikan nilainilai agama, martabat manusia Indonesia, atau merusak hubungan internasional.

Terkait dengan pertanggungjawaban pidana, ketentuan Pasal 57 Undang-Undang Penyiaran diduga mengandung kelemahan karena tidak menyebut dengan jelas siapa yang dimaksud "setiap orang" sebagai pelaku tindak pidana pelanggaran isi siaran. Apakah yang dimaksud setiap orang tersebut adalah orang per orang yang berhubungan dengan 
perbuatan, ataukah termasuk "korporasi" yang menaungi televisi yang menayangkan siaran yang dilarang tersebut. Kalau yang dimaksudkan hanyalah orang per orang, maka jelas ketentuan pidana ini menjadi sangat lemah, karena sama sekali tidak akan menimbulkan efek penjeraan bagi perusahaan televisi bersangkutan. Namun kalau juga menyangkut korporasi, Undang-Undang Penyiaran saama sekali tidak mengatur tentang kapan perbuatan pidana menyiarkan tayangan yang dilarang, dapat dibebankan pertanggungjawaban pidananya kepada korporasi.

Dengan demikian, terdapat kekaburan norma atau norma yang tidak jelas (unclear norm/vague van normen) di dalam Pasal 57 Undang-Undang Penyiaran, sedemikian sehingga ketentuan pasal dimaksud tidak mampu menjadi sarana penegakan hukum yang efektif terhadap pelaku perbuatan penayangan siaran televisi yang dapat menimbulkan dan atau meningkatkan angka kriminalitas di kalangan anak-anak.

\section{B. Perumusan Masalah}

Berdasarkan latar belakang yang telah penulis paparkan diatas, maka penulis merumuskan pokok permasalahan sebagai berikut :

1. Bagaimanakah Analisis Perumusan Norma Hukum Tentang Penayangan Siaran Pertelevisian yang Dapat Menyebabkan Terjadinya Kriminalitas Anak Menurut Undang-Undang Penyiaran?

2. Bagaimanakah Kebijakan Hukum Pidana yang Sebaiknya Dinormakan di Dalam Undang-Undang Penyiaran di Masa Depan? gar hukum pidana atau tindak pidana yang dilakukan oleh anak.

\section{Metode Penelitian}

\section{Tipe Penelitian}

Mengacu pada perumusan masalah dan tujuan penelitian tersebut di atas, maka penelitian ini dilakukan dengan menggunakan penelitian hukum normatif. Penelitian hukum normatif mencakup penelitian terhadap asas-asas hukum, sistematika hukum, sinkronisasi hukum, dan sejarah hukum.

Penelitian normatif diambil sebagai pendekatan dalam penelitian ini karena yang menjadi perhatian utama adalah ketentuan perundang-undangan yang mengatur mengenai perbuatan pidana dan sanksi pidana penayangan siaran televisi yang dapat menyebabkan terjadinya kriminalitas di kalangan anak-anak. 
2. Pendekatan yang Digunakan

Berdasarkan tipe penelitian normatif tersebut di atas, maka pendekatan yang digunakan dalam penelitian ini adalah pendekatan konseptual (conceptual approach), pendekatan perundang-undangan (normative approach) dan pendekatan sejarah (historical approach).

Terkait dengan pendekatan tersebut, dalam penelitian ini akan digambarkan tentang hal-hal yang berkaitan dengan perbuatan dan pertanggungjawaban pidana penyiaran.

Setelah bahan-bahan hukum tersebut terkumpul, maka dilakukan analisis dengan cara:

a. Menginterpretasikan semua peraturan perundang-undangan sesuai masalah yang dibahas.

b. Mengevaluasi peraturan perundang-undangan yang berhubungaı dengan masalah yang diteliti.

c. Menilai bahan-bahan hukum yang berhubungan dengan masalah yang dibahas.

\section{Tinjauan Yuridis Terhadap Siaran Pertelevisian Yang Menyebabkan} Keiminalitas Anak Berdasarkan Undang-Undang Nomor 32 Tahun 2002 Tentang

\section{Penyiaran}

1. Analisis Perumusan Norma Hukum Tentang Penayangan Siaran Pertelevisian yang Dapat Menyebabkan Terjadinya Kriminalitas Anak Menurut Undang-Undang Penyiaran

Media massa sangat berperan dalam perkembangan atau bahkan perubahan pola tingkah laku dari suatu masyarakat, oleh karena itu kedudukan media massa dalam masyarakat sangatlah penting. Dengan adanya media massa, masyarakat yang tadinya dapat dikatakan tidak beradab dapat menjadi masyarakat yang beradab. Hal itu disebabkan, oleh karena media massa mempunyai jaringan yang luas dan bersifat massal sehingga masyarakat yang membaca tidak hanya orang-perorang tapi sudah mencakup jumlah puluhan, ratusan, bahkan ribuan pembaca, sehingga pengaruh media massa akan sangat terlihat di permukaan masyarakat.

Sedangkan menurut Naina Akhmadsyah dan M. Alwi Dahlan, media massa dipandang punya kedudukan strategis dalam masyarakat. Terdapat tiga fungsi instrumental media massa, yaitu untuk memenuhi fungsi pragmatis bagi kepentingan pemilik media massa sendiri, bagi kekuatan-kekuatan ekonomi dan politik dari pihak di luar media massa, 
atau untuk kepentingan warga masyarakat. Secara konseptual, keberadaan media massa dan masyarakat perlu dilihat secara bertimbal balik. ${ }^{5}$

Harold D Lasswell dan Charles Wright, seperti dikutip Naina Akmadsyah dkk, menyatakan terdapat empat fungsi sosial media massa. Pertama, sebagai social surveilance. Pada fungsi ini, media massa termasuk media televisi, akan senantiasa merujuk pada upaya penyebaran informasi dan interpretasi seobjektif mungkin mengenai peristiwa yang terjadi, dengan maksud agar dapat dilakukan kontrol sosial sehingga tidak terjadi hal-hal yang tidak diinginkan dalam lingkungan masyarakat bersangkutan. ${ }^{6}$

Kedua, sebagai social correlation. Dengan fungsi korelasi sosial tersebut, akan terjadi upaya penyebaran informasi yang dapat menghubungkan satu kelompok sosial dengan kelompok sosial lainnya. Begitupun antara pandangan-pandangan yang berbeda, agar tercapai konsensus sosial. ${ }^{7}$

Ketiga, fungsi socialization. Pada fungsi ini, media massa selalu merujuk pada upaya pewarisan nilai-nilai luhur dari satu generasi ke generasi selanjutnya, atau dari satu kelompok ke kelompok lainnya. Keempat, fungsi entertainment. Agar tidak membosankan, sudah tentu media massa perlu juga menyajikan hiburan kepada khalayaknya. Hanya saja, fungsi hiburan ini sudah terlalu dominan mewarnai siaran televisi kita, sehingga ketiga fungsi lainnya, seolah telah terlupakan. Untuk itu, fungsi hiburan haruslah ditata agar seimbang dengan 3 (tiga) fungsi lainnya. ${ }^{8}$

Sejatinya, keempat fungsi media massa tersebut bersinergi dan sinkron dalam rangka menyajikan tontonan yang sehat. Sebab, hanya dengan tontonan yang sehat sajalah yang nantinya dapat melahirkan generasi yang sehat. Generasi yang memiliki karakter bangsa. Dalam hal inilah, kesadaran masyarakat dunia pada umumnya dan Indonesia secara khusus perlu bertekad dan berkomitmen untuk mengupayakan agar ke depan jangan lagi mau membiarkan diri dan keluarganya didikte oleh siaran televisi yang tidak mendidik dan bahkan merusak pembangunan karakter bangsa bagi masyarakat (warga negara) dalam pembangunan bangsa ke depan. ${ }^{9}$

Dari penjelasan diatas, dapatdisimpulkan bahwa peran media massa dalam mentransformasikan nilai-nilai kebangsaan merupakan suatu yang sudah seharusnya dan

\footnotetext{
${ }^{5}$ Naina Akhmadsyah, M Alwi Dahlan, dkk (2008). Manusia Komunikasi Komunikasi Manusia, PT. Kompas Media Nusantara, Jakarta, 2008, hal. 45.

${ }^{6}$ Ibid. hal. 421-422.

${ }^{7}$ Ibid.

${ }^{8}$ Ibid.

${ }^{9}$ Ibid.
} 
media kita sesungguhnya sudah dan terus melakukannya. Persoalan yang ada, media cukup kesulitan mengangkat nilai-nilai kebangsaan dalam bentuk nyata karena tidak atau belum menemukan nara sumber, tokoh atau fakta-fakta yang dapat atau benar-benar layak menjadi ikon, panutan dalam mentransformasikan nilai-nilai kebangsaan yang relevan dengan kondisi kehidupan saat ini.

Tidak dapat dipungkiri peran televisi saat ini semakin meningkat, bah-kan telah menjadi kebutuhan masyarakat yang penting. Peranannya sebagai media komunikasi audio-visual sangat luar biasa dibandingkan mediamassa yang lain. Perkembangan teknologi komunikasi massa,khususnya televisi banyak membantu manusia untuk mengatasi pelbagai hambatan dalam berkomunikasi dan memperbaiki kualitas hidupnya. Khalayak dapat menge-tahui apa yang terjadi di seluruh dunia jauh lebih cepat, bahkan sering kali khalayak lebih dahulu mengetahui apa yang terjadi jauh di luar nege-ri daripada di dalam negeri.

Efek positif media televisi dalam pembangunan manusia secara sederhana,terjadi pada tataran individu dan tataran masyarakat (sosial) mela-lui fungsifungsi yang diperankan televisi. Pada tataran individu, efek positif yang diberikan televisi melalui fungsinya adalah meliputi fungsi infor-masi; fungsi pendidikan; fungsi menghibur; fungsi mempengaruhi; fungsi proses pengembangan mental, fungsi adaptasi lingkungan, fungsi manipulasi lingkungan, fungsi meyakinkan, fungsi menganugrahkan status, fungsi mem-bius, fungsi menciptakan rasa kebersatuan, fungsi privatisasi, dan fung-si kontrol sosial. ${ }^{10}$

Sedangkan pada tataran masyarakat (sosial), efek positif yang diberi-kan televisi melalui fungsinya antara lain meliputi: relationship (berhubung-an), dimana media massa televisi dapat bertindak sebagai jembatan silaturahmi diantara individu dan lingkungan; socialization (pewarisan nilai-nilai), dari satu generasi manusia ke

generasi manusia berikutnya, contoh: musawarah mufakat atau gotong royong; surveillance (pengawasan), yang terbagi atas warning before surveillance(pengawasan peringatan), contoh: flu burung dan instrumental surveillance (pengawasan instrumental), contoh: resep masakan; to development (untuk pembangunan), contoh: ajakan parti-sipasi peningkatan program keluarga berencana nasional, interpretation (penafsiran), contoh: tajuk rencana;

\footnotetext{
${ }^{10}$ Ibid.hal. 7.
} 
linkage (pertalian), dimana media massa televisi dapat menyatukan anggota masyarakat yang beragam, sehingga membentuk linkage minat yang sama, contoh: solidaritas untuk Palestina; transmission of values (penyebaran nilai-nilai), contoh: sarana dakwah; to learn (sarana pembelajaran), contoh: belajar bahasa. ${ }^{11}$

Media televisi sesungguhnya memiliki kelebihan dalam membantu tugas guru dan orangtua dalam menanamkan pendidikan karakter terhadap anak secara berkesinambungan. Hal ini karena televisi dengan menyajikan pesan audiovisual dan gerak, serta dapat mendramatisir dan memanipulasi pesan sesuai tujuan yang dikehendaki. Materi televisi akan berpengaruh positif terhadap pembentukan karakter anak jika ia didesain melalui contoh-contoh konkret dalam kehidupan masyarakat, berbangsa, dan bernegara. $^{12}$

Di samping dampak positif di atas, keberadaan televisi sebagai sebuah kebutuhan keluarga, juga membawa dampak negatif. Terkait dengan dampak negatif dari tayangan televisi, Litlejohn Stephen W \& Foss, Karen A., yang menguraikan bahwa:

Efek tayangan yang disiarkan ditelevisi akan mempengaruhi persepsi penontonnya. Salah satunya adalah efek tayangan yang memuat kekerasan akan dapat menimbulkan efek-efek sebagai berikut:

1. Catharsis: tayangan kekerasan di media massa dapat digunakan sebagai mekanisme katarsis bagi penonton untuk melampiaskan fantasinya tentang kekerasan sehingga dapat mengurangi perilaku kekerasan yang ada

2. Social learning: tayangan kekerasan dapat dijadikan sebagai model belajar bagi penonton.

3. Priming: ketika tayangan kekerasan berlangsung terus menerus dan ditonjolkan, dapat memberikan dampak jangka panjang pada penonton.

4. Arousal: membangkitkan perilaku kekerasan dalam diri penonton

5. Desensitization: menjadikan penonton tidak lagi sensitif atau peka terhadap perilaku kekerasan, lama-lama dianggap sebagai hal yang biasa.

6. Fear: menimbulkan dampak ketakutan. ${ }^{13}$

\footnotetext{
${ }^{11}$ Ibid.

${ }^{12}$ Ibid.

${ }^{13}$ Littlejohn,Stephen W. \& Foss, Karen A., Theories of Human Communication, $8^{\text {th }}$ edition, Thomson Wadsworth, USA, 2005, hal. 43.
} 
Sejalan dengan pendapat di atas, Tim Pakar Yayasan Jati Diri Bangsa mengemukakan bahwa "Dalam era kemajuan teknologi informasi dan telekomunikasi saat ini, salah satu faktor yang berpengaruh sangat besar dalam pembangunan, atau sebaliknya pengrusakan karakter masyarakat atau bangsa adalah media massa, khususnya media elektronik dengan pelaku utama adalah televisi. ${ }^{14}$

Sementara itu Dennis McQuil mengatakan lebih jauh tentang pengaruh media sebagai berikut: Media menjangkau lebih banyak orang dibandingkan daripada institusiinstitusi lainnya. Dan lebih parah lagi, media massa sudah sejak dahulu telah "mengambil alih" peranan sekolah, orang tua, agama dan lain-lain. Institusi media sendiri sebenarnya tidaklah memiliki kekuasaan, akan tetapi insitusi ini selalu berkaitan dengan kekuasaan negara. Lebih lanjut dia mengatakan tentang ciri utama dari komunikasi massa. Komunikasi massa memiliki ciri yang khas, yaitu: Bahwa hubungan antara pengirim dan penerima bersifat satu arah dan jarang sekali, bukan berarti tidak ada, yang bersifat interaktif. Kalaupun ada, maka itu terselenggara dengan tidak seimbang antara pengirim dan penerima. Pengirim biasanya akan sangat dominan karena berperan sebagai penyelenggara. Yang lebih parah lagi adalah bahwa hubungan tersebut juga bersifat impersonal, bahkan mungkin sekali akan sering bersifat non moral, dalam pengertian bahwa sang pengirim biasanya tidak bertanggung jawab atas konsekuensi yang terjadi pada para individu, dalam hal ini pihak penerima. ${ }^{15}$

Masih terkait dengan dampak buruk televisi terhadap karakter bangsa, Muhammad Iksan berpandangan bahwa media massa sekarang memakai teknologi yang makin lama makin canggih. Namun tanpa kecerdasan dan kearifan, media massa yang didukung teknologi canggih tersebut justru akan melemahkan atau merusak karakter bangsa. Saya tidak ragu mengatakan, media elektronik di Indonesia, khususnya televisi, sekarang ini kontribusinya 'nihil' dalam pembangunan karakter bangsa. Saya tidak bermaksud untuk mengatakan bahwa tidak ada program televisi yang baik. Namun sebagian besar program televisi justru lebih menonjolkan karakter buruk daripada karakter baik. Sering kali pengaruh lingkungan keluarga yang baik justru dirusak oleh siaran media televisi. Di keluarga, anak-anak dididik untuk menghindari kekerasan, namun acara TV justru penuh dengan adegan kekerasan. Di rumah, anak-anak dididik untuk hidup sederhana, namun

\footnotetext{
${ }^{14}$ Tim Pakar Jati Diri Bangsa, Pendidikan Karakter di Sekolah, Dari Gagasan ke Tindakan, Elex Media Komputindo, Jakarta, 2011, hal. 45.

15 Muhammad Iksan, Op. Cit., hal. 9.
} 
acara sinetron di tevisi Indonesia justru memamerkan kemewahan. Di rumah anak-anak dididik untuk hidup jujur, namun tayangan di televisi Indonesia justru secara tidak langsung menunjukkan 'kepahlawanan' tokoh-tokoh yang justru di mata publik di anggap 'kaisar' atau 'pangeran-pangeran' koruptor. Para guru agama mengajarkan bahwa membicarakan keburukan orang lain dan bergosip itu tidak baik, namun acara televisi, khususnya infotainment, penuh dengan gosip. Bapak dan ibu guru di sekolah mendidik para murid untuk berperilaku santun, namun suasana sekolah di sinetron Indonesia banyak menonjolkan perilaku yang justru tidak santun dan melecehkan guru. Secara umum, banyak tayangan di televisi Indonesia, justru 'membongkar' anjuran berperilaku baik yang ditanamkan di di rumah oleh orang tua dan oleh para guru di sekolah. ${ }^{16}$

Semakin sulit ditemukan acara di televisi yang "inspiring" dan "mendidik", dengan tujuan turut membangun karakter bangsa. Selain lawakan dan acara sinetron tentang "setan", sinetron opera sabun adalah merupakan jenis acara yang dapat bertahan selama ber bulan-bulan. Alasannya sederhana sekali yaitu, mereka (televisi) memilih acara yang dapat menaikkan "rating" mereka, sehingga dapat mengundang banyak pemasang iklan yang berarti meningkatkan pendapatan. Belum lagi bila kita berbicara tentang segmen acara infotaintment yang sedang marak belakangan ini, berita-berita gosip atau cerita burung tentang para seleberitis. Tidak diketahui dengan pasti mana yang benar dan mana pula yang hanya isapan jempol belaka. Menurut pengamatan penulis selama 1 minggu berturut-turut, 7 dari 10 stasiun televisi yang umum ditonton masyarakat, dalam 1minggu stasiun-stasiun televisi tersebut menyiarkan selama 14 jam setiap harinya tayangan berita gosip dan infotaiment yang bersifat nonakademik bahkan cenderung bersifat meresahkan dan mengajarkan sifat su'udzon kepada masyarakat. ${ }^{17}$

Kemudian, menurut hasil penelitian American Psychological Asociation (APA) pada tahun 1995 terungkap bahwa tayangan yang bermutu akan mempengaruhi seseorang untuk berperilaku baik. Adapun tayangan yang kurang bermutu akan memengaruhi seseorang untuk berperilaku buruk. Bahkan, penelitian ini menyimpulkan bahwa hampir semua perilaku buruk yang dilakukan orang adalah hasil pelajaran yang mereka terima dari media semenjak usia anak-anak. ${ }^{18}$

\footnotetext{
${ }^{16}$ Muhammad Iksan, Op. Cit., hal. 3.

${ }^{17}$ Ibid.

${ }^{18}$ Zubaedi, Desain Pendidikan Karakter: Konsepsi dan Aplikasinya dalam Lembaga Pendidikan, Kencana, Jakarta, 2011, hal. 174.
} 
Berdasarkan pendapat para ahli di atas, dapat dilihat dengan jelas betapa besarnya pengaruh tayangan televisi terhadap pembentukan karakter, terutama karakter anak. Tayangan yang bersifat anti sosial dan tidak mendidik, telah meluluh-lantakkan penghargaan anak terhadap nilai-nilai kesopanan, kesusilaan, kedisiplinan dan etos untuk bekerja keras.

Tayangan kenakalan remaja secara berlebihan, seperti tawuran, penyalah-gunaan narkotika, geng motor dan lain sebagainya, tanpa disadari telah menjadi model pembelajaran yang demikian efektif bagi anak, untuk kemudian terdorong melakukan tindakan serupa.

Tragisnya, karena rasa ingin tahu yang demikian tinggi sebagaimana layaknya dimiliki oleh anak-anak, tayangan negatif televisi, telah menjerembabkan anak-anak, permata keluarga dan tunas harapan bangsa, ke lembah pencandu narkotika, penikmat pergaulan bebas, kesadisan geng motor, bahkan menjadi pelaku kejahatan serius seperti pencurian, perampokan, pemerkosaan, bahkan pembunuhan.

Demi mencermati dampak negatif penyiaran televisi terutama terhadap kriminalitas anak, dirasakan perlunya pengaturan yang lebih tegas dan jelas tentang penyiaran televisi, sedemikian sehingga pengaturan tersebut mampu mencegah lahirnya perilaku kriminalitas, terutama di kalangan anak-anak, akibat menonton acara televisi yang tidak mendidik dan mendorong anak berbuat kejahatan.

Sebagaimana telah dikemukakan sebelumnya, bahwa dalam perspektif perundangundangan Indonesia, penyelenggaraan penyiaran diatur di dalam Undang-Undang Penyiaran. Terkait dengan isi siaran, Undang-Undang Penyiaran mengatur secara khusus di dalam Bagian Pertama dari Bab IV mengenai Pelaksanaan Siaran, yang meliputi Pasal 35 dan Pasal 36. Di dalam Pasal 35 pada pokoknya diatur bahwa "Isi siaran harus sesuai dengan asas, tujuan, fungsi, dan arah siaran sebagaimana dimaksud dalam Pasal 2, Pasal 3, Pasal 4, dan Pasal 5".

Sementara di dalam Pasal 36 digariskan tentang detail isi siaran, yang selengkapnya menyatakan bahwa:

\section{Pasal 36}

(1) Isi siaran wajib mengandung informasi, pendidikan, hiburan, dan manfaat untuk pembentukan intelektualitas, watak, moral, kemajuan, kekuatan bangsa, menjaga persatuan dan kesatuan, serta mengamalkan nilai-nilai agama dan budaya Indonesia. 
(2) Isi siaran dari jasa penyiaran televisi, yang diselenggarakan oleh Lembaga Penyiaran Swasta dan Lembaga Penyiaran Publik, wajib memuat sekurang-kurangnya $60 \%$ (enam puluh per seratus) mata acara yang berasal dari dalam negeri.

(3) Isi siaran wajib memberikan perlindungan dan pemberdayaan kepada khalayak khusus, yaitu anak-anak dan remaja, dengan menyiarkan mata acara pada waktu yang tepat, dan lembaga penyiaran wajib mencantumkan dan/atau menyebutkan klasifikasi khalayak sesuai dengan isi siaran.

(4) Isi siaran wajib dijaga netralitasnya dan tidak boleh mengu-tamakan kepentingan golongan tertentu.

(5) Isi siaran dilarang:

a. bersifat fitnah, menghasut, menyesatkan dan/atau bohong;

b. menonjolkan unsur kekerasan, cabul, perjudian, penyalah-gunaan narkotika dan obat terlarang; atau

c. mempertentangkan suku, agama, ras, dan antar golongan.

(6) Isi siaran dilarang memperolokkan, merendahkan, melecehkan dan/atau mengabaikan nilai-nilai agama, martabat manusia Indonesia, atau merusak hubungan internasional.

Mencermati ketentuan Pasal 35 dan 36 Undang-Undang Penyiaran tersebut di atas, terlihat dengan jelas bahwa Undang-Undang Penyiaran telah mengatur dengan jelas dan tegas tentang bentuk-bentuk siaran yang dilarang untuk ditayangkan. Tayangan yang jelasjelas dilarang tersebut adalah tayangan yang bersifat fitnah, menghasut, menyesatkan dan/atau bohong, menonjolkan unsur kekerasan, cabul, perjudian, penyalah-gunaan narkotika dan obat terlarang, atau mempertentangkan suku, agama, ras, dan antar golongan, serta tayangan yang memperolokkan, merendahkan, melecehkan dan/atau mengabaikan nilai-nilai agama, martabat manusia Indonesia, atau merusak hubungan internasional.

Larangan terhadap tayangan yang anti sosial, tidak mendidik dan mendorong lahirnya kriminalitas tersebut, kemudian diperkuat dan dipertegas lagi dengan adanya ketentuan mengenai sanksi yang dapat dijatuhkan terhadap orang dan/atau lembaga 
penyiaran yang melanggar ketentuan tersebut. Sanksi dimaksud dapat berupa sanksi administratif dan sanksi pidana.

Bentuk-bentuk sanksi administratif yang dapat dijatuhkan kepada pelanggar isi siaran, diatur di dalam Pasal 55 ayat (2), yang pada pokoknya menggariskan bahwa sanksi administratif dapat berupa teguran tertulis; penghentian sementara mata acara yang bermasalah setelah melalui tahap tertentu; pembatasan durasi dan waktu siaran; denda administratif; pembekuan kegiatan siaran untuk waktu tertentu; tidak diberi perpanjangan izin penyelenggaraan penyiaran; atau pencabutan izin penyelenggaraan penyiaran.

Sementara itu, sanksi pidana yang dapat dijatuhkan kepada setiap orang yang melakukan pelanggaran terhadap larangan sebagaimana termaktub di dalam Pasal 36 Undang-Undang Penyiaran, digariskan di dalam Pasal 57 yang pada pokoknya menyatakan bahwa setiap orang yang melanggar ketentuan penyiaran televisi dalam Pasal 36 ayat (5) dan (6), dipidana dengan pidana penjara paling lama 5 (lima) tahun dan/atau denda paling banyak Rp. 10.000.000.000,00 (sepuluh miliar rupiah).

Merujuk pada ketentuan pidana di dalam Pasal 57 di atas, disimpulkan bahwa perbuatan menyiarkan tayangan yang bersifat fitnah, menghasut, menyesatkan dan/atau bohong, menonjolkan unsur kekerasan, cabul, perjudian, penyalah-gunaan narkotika dan obat terlarang, atau mempertentangkan suku, agama, ras, dan antar golongan, serta tayangan yang memperolokkan, merendahkan, melecehkan dan/atau mengabaikan nilainilai agama, martabat manusia Indonesia, atau merusak hubungan internasional, adalah perbuatan pidana, yang oleh karenanya apabila perbuatan itu dilakukan, pelakunya dapat dijatuhi pidana.

Dengan demikian, untuk mecegah penayangan siaran televisi yang tidak mendidik, anti sosial, dan merusak moral dan karakter bangsa terutama anak-anak, dan berpotensi memicu kriminalitas anak, Undang-Undang Penyiaran sesungguhnya telah menerapkan sanksi yang bersifat komprehensif, dimana pelanggar tidak hanya dapat dikenakan sanksi administratif, melainkan juga sanksi pidana, yang semestinya menimbulkan efek penjeraan (deterrence aspect).

Apabila demikian halnya, maka pertanyaan yang muncul adalah manakala larangan penayangan siaran televisi yang bersifat tidak mendidik, anti sosial dan merusak moral dan karakter anak, telah disertai dengan sanksi administratif dan sanksi pidana, mengapa tayangan yang berpotensi memicu kriminalitas anak itu, justeru semakin marak di televisitelevisi?. 
Lebih jelasnya, apakah ada kelemahan di dalam perumusan ketentuan pidana di dalam Pasal 57 Undang-Undang Penyiaran, sedemikian sehingga ketentuan pidana itu tidak mampu menjadi sarana hukum yang efektif untuk menghapus dan atau setidaknya mencegah penayangan yang dapat memicu terjadinya kriminalitas di kalangan anak-anak?

Untuk menjawab pertanyaan tersebut, dilakukan analisis terhadap perumusan ketentuan pidana, yang dibangun di atas dua fondasi, yakni fondasi unsur-unsur tindak pidana, dan fondasi pertanggungjawaban pidana atau sanksi pidana yang dapat dijatuhkan terhadap pelaku yang memenuhi unsur-unsur pidana dimaksud.

Analisis Unsur-unsur Tindak Pidana Isi Penyiaran

Ditinjau dari unsur-unsur tindak pidana, maka tindak pidana sebagaimana dimaksud di dalam Pasal 57 Undang-Undang Penyiaran, mengandung 2 (dua) unsur, yakni:

1. Unsur subjektif "setiap orang";

2. Unsur objektif "menyiarkan tayangan yang bersifat fitnah, menghasut, menyesatkan dan/atau bohong, menonjolkan unsur kekerasan, cabul, perjudian, penyalah-gunaan narkotika dan obat terlarang, atau mempertentangkan suku, agama, ras, dan antar golongan, serta tayangan yang memperolokkan, merendahkan, melecehkan dan/atau mengabaikan nilai-nilai agama, martabat manusia Indonesia, atau merusak hubungan internasional".

Terhadap 2 (dua) unsur tindak pidana di atas, dilakukan analisis, dengan hasil sebagai berikut:

1. Unsur subjektif "setiap orang":

Setelah dicermati, Undang-Undang Penyiaran tidak menyebut dengan jelas siapa yang dimaksud "setiap orang" sebagai pelaku tindak pidana pelanggaran isi siaran. Apakah yang dimaksud setiap orang tersebut adalah orang per orang yang berhubungan dengan perbuatan, ataukah termasuk "korporasi" yang menaungi televisi yang menayangkan siaran yang dilarang tersebut. Kalau yang dimaksudkan hanyalah orang per orang, maka jelas ketentuan pidana ini menjadi sangat lemah, karena pada setiap terjadinya pidana isi siaran, yang dapat dijerat sebagai pelaku dan dijatuhi pidana adalah orang per orang saja, sedemikian sehingga pengaturan tentang pidana penyiaran yang berpotensi menimbulkan kriminalitas anak tersebut, sama sekali tidak akan dapat menjerat korporasi yang menaungi 
perusahaan televisi bersangkutan. Pembebanan pertanggungjawaban pidana hanya kepada orang per orang, tentu saja tidak akan pernah menimbulkan efek penjeraan (deterrence aspect), yang pada gilirannya tidak akan berdampak apapun terhadap upaya menghentikan perusakan moral dan perilaku anak, akibat tontonan televisi dengan isi siaran yang tidak mendidik dan mendorong tumbuh suburnya kriminalitas anak.

Namun kalau juga menyangkut korporasi, Undang-Undang Penyiaran saama sekali tidak mengatur tentang kapan perbuatan pidana menyiarkan tayangan yang dilarang, dapat dibebankan pertanggungjawaban pidananya kepada korporasi, atau dalam keadaan yang bagaimana, sebuah perbuatan pidana yang dilakukan oleh orang per orang, dapat dijatuhkan pertanggungjawabannya kepada korporasi.

2. Unsur objektif "menyiarkan tayangan yang bersifat fitnah, menghasut, menyesatkan dan/atau bohong, menonjolkan unsur kekerasan, cabul, perjudian, penyalah-gunaan narkotika dan obat terlarang, atau mempertentangkan suku, agama, ras, dan antar golongan, serta tayangan yang memperolokkan, merendahkan, melecehkan dan/atau mengabaikan nilai-nilai agama, martabat manusia Indonesia, atau merusak hubungan internasional":

Setelah meneliti ketentuan Pasal 57 Undang-Undang Penyiaran, ditemukan fakta bahwa pasal dimaksud tidak memuat ketentuan yang jelas dan tegas tentang ukuran, kriteria dan batasan yang jelas tentang apa yang dimaksud dengan, atau kapan sebuah tayangan dapat dikatakan sebagai tayangan yang bersifat fitnah, menghasut, menyesatkan dan/atau bohong, menonjolkan unsur kekerasan, cabul, perjudian, penyalah-gunaan narkotika dan obat terlarang, atau mempertentangkan suku, agama, ras, dan antar golongan, serta tayangan yang memperolokkan, merendahkan, melecehkan dan/atau mengabaikan nilai-nilai agama, martabat manusia Indonesia, atau merusak hubungan internasional. Ketiadaan penjelasan dan kriteria tentang maksud dari masing-masing perbuatan tersebut, menyebabkan ketentuan Pasal 57 dimaksud menjadi ketentuan yang multi tafsir. Penegak hukum pada masing-masing tahapan peradilan pidana, akan memiliki tafsirnya sendiri tentang apa yang maksud dengan perbuatan pidana bersangkutan. 
Keadaan yang demikian, jelas akan menyebabkan kerancuan penerapan hukum oleh penegak hukum di lapangan, yang pada gilirannya akan menimbulkan ketidak-pastian hukum dan ketidak-adilan.

Berdasarkan analisis di atas, disimpulkan bahwa Undang-Undang Penyiaran tidak memuat ketentuan yang jelas dan tegas tentang unsur-unsur tindak pidana pelanggaran isi siaran, dan pihak yang dapat dimintai pertanggungjawaban pidana apabila, terjadi perbuatan pidana pelanggaran isi siaran yang berpotensi menimbulkan kriminalitas anak. Kaburnya norma yang mengatur tentang unsur-unsur tindak pidana pelanggaran isi siaran, telah menyebabkan Pasal 57 Undang-Undang Penyiaran tidak dapat diterapkan secara efektif untuk menangkal terjadinya perbuatan pidana pelanggaran isi siaran yang dapat memicu lahirnya kriminalitas anak

\section{Analisis Unsur Pertanggungjawaban Pidana}

Sebagaimana telah diuraikan di muka bahwa menurut ketentuan Pasal 57 UndangUndang Penyiaran, terhadap pelaku perbuatan pidana pelanggaran isi siaran, dipidana dengan pidana penjara paling lama 5 (lima) tahun dan/atau denda paling banyak Rp. 10.000.000.000,00 (sepuluh miliar rupiah).

Secara normatif perumusan pidana maksimum di dalam Pasal 57 Undang-Undang Penyiaran dapat difahami, dimana dalam penerapan oleh Hakim akan disesuaikan dengan keyakinan Hakim terhadap tingkat kesalahan pelaku yang menyiarkan tayangan yang bersifat fitnah, menghasut, menyesatkan dan/atau bohong, menonjolkan unsur kekerasan, cabul, perjudian, penyalah-gunaan narkotika dan obat terlarang, atau mempertentangkan suku, agama, ras, dan antar golongan, serta tayangan yang memperolokkan, merendahkan, melecehkan dan/atau mengabaikan nilai-nilai agama, martabat manusia Indonesia, atau merusak hubungan internasional.

Artinya, apabila Hakim berdasarkan fakta-fakta di persidangan, meyakini bahwa tingkat kesalahan pelaku tergolong kecil dalam terjadinya suatu pelanggaran isi siaran, maka hukuman yang dijatuhkan akan lebih rendah, dibandingkan apabila Hakim meyakini bahwa tingkat kesalahan pelaku tergolong besar dalam terjadinya suatu pelanggaran isi siaran, maka hukuman yang dijatuhkan juga akan lebih besar.

Namun demikian, walaupun dapat difahami dan sudah berlaku secara umum di dalam perundang-undangan pidana Indonesia selama ini, perumusan atau formulasi pidana maksimum, bukan berarti tidak mengandung kelemahan. 
Perumusan sanksi pidana yang hanya mengatur mengenai pidana maksimum terhadap pelaku pidana pelanggaran isi siaran, dapat melemahkan penegakan hukum terhadap perbuatan pidana dimaksud. Dengan kata lain, kiranya dapat dikatakan bahwa sangat mungkin terjadi karena keyakinan hakim akibat dari penafsirannya terhadap ketentuan pidana dalam Undang-Undang Penyiaran dan atau karena kurang jelasnya delik dalam ketentuan pidana Undang-Undang dimaksud, hakim menjatuhkan pidana yang sangat rendah terhadap pelaku tindak pidana penyiaran.

Artinya, betapapun unsur-unsur perbuatan pidana "menyiarkan tayangan yang bersifat fitnah, menghasut, menyesatkan dan/atau bohong, menonjolkan unsur kekerasan, cabul, perjudian, penyalah-gunaan narkotika dan obat terlarang, atau mempertentangkan suku, agama, ras, dan antar golongan, serta tayangan yang memperolokkan, merendahkan, melecehkan dan/atau mengabaikan nilai-nilai agama, martabat manusia Indonesia, atau merusak hubungan internasional", sebagaimana dimaksud di dalam Pasal 57 UndangUndang Penyiaran terpenuhi, dengan formulasi pidana paling lama 5 (lima) tahun dan/atau denda paling banyak Rp. 10.000.000.000,00 (sepuluh miliar rupiah), Hakim berdasarkan keyakinannya dapat menjatuhkan pidana mulai dari 1 (satu) hari sampai dengan 5 (lima) tahun.

Dengan pengaturan yang demikian, kriteria penjatuhan pidana terhadap pelaku penyiaran yang melakukan tindak pidana pelanggaran isi siaran, menjadi sangat bergantung pada keyakinan, sikap kalbu dan persepsi dari hakim. Dengan demikian, dapat dikatakan bahwa pengenaan pidana penyiaran menjadi kewenangan atau diskresi dari hakim.

Menyerahkan sepenuhnya pada kewenangan hakim yang bersifat eksklusif untuk menjatuhkan putusan pidana yang ketentuan pidananya hanya mengatur pidana maksimum, akan menyebabkan disparitas yang tinggi dalam putusan hakim terhadap tindak pidana penyiaran, terutama yang dapat memicu lahirnya kriminalitas anak.

Disparitas atau perbedaan putusan tersebut bisa terjadi karena faktor keyakinan hakim. Namun di sisi lain, bisa pula terjadi karena adanya praktik tidak terpuji seperti suap menyuap dan pemufakatan jahat yang dilakukan oleh pelaku tindak pidana dengan hakim yang memiliki kepribadian yang tercela dan tidak memiliki integritas, akibat begitu besarnya peluang yang diberikan oleh Undang-Undang.

Dalam bahasa yang lebih sederhana, kiranya dapat dikatakan bahwa karena Undang-Undang memungkinkannya, hakim yang tidak menjunjung tinggi harkat dan 
keluhuran martabatnya, akan dengan mudah menjatuhkan pidana yang ringan bagi yang membayar dan sebaliknya tmenjatuhkan pidana yang tinggi bagi yang tidak mampu atau tidak mau membayar.

Dengan demikian, maka menjadi jelas bahwa pengaturan hukum melalui formulasi sanksi pidana yang hanya mengatur pidana maksimum, akan cenderung menimbulkan ketidak-pastian hukum dan rasa ketidak-adilan di tengah masyarakat. Apabila pengaturan hukum tidak mampu menciptakan keadilan dan kepastian hukum, maka pengaturan hukum tersebut menjadi tidak bermanfaat atau tidak membawa kemanfaatan hukum.

Merujuk pada analisis di atas, diambil kesimpulan pada bagian ini bahwa perumusan norma hukum tentang penayangan siaran pertelevisian yang dapat menyebabkan terjadinya kriminalitas anak, diatur di dalam Pasal 57 Undang-Undang Penyiaran, yang pada intinya menggariskan bahwa setiap orang yang menyiarkan tayangan yang bersifat fitnah, menghasut, menyesatkan dan/atau bohong, menonjolkan unsur kekerasan, cabul, perjudian, penyalah-gunaan narkotika dan obat terlarang, atau mempertentangkan suku, agama, ras, dan antar golongan, serta tayangan yang memperolokkan, merendahkan, melecehkan dan/atau mengabaikan nilai-nilai agama, martabat manusia Indonesia, atau merusak hubungan internasional, dipidana dengan pidana penjara paling lama 5 (lima) tahun dan/atau denda paling banyak Rp. 10.000.000.000,00 (sepuluh miliar rupiah). Norma ketentuan pidana tersebut pada kenyataannya tidak dapat dijadikan sarana hukum yang efektif untuk menangkal munculnya tayangan televisi yang berdampak pada lahirnya kriminalitas anak, karena perumusannya mengandung sejumlah kelemahan. Kelemahan pertama, terletak pada perumusan unsur-unsur tindak pidana yang tidak secara jelas dan tegas menggariskan tentang batasan dari masing-masing perbuatan pidana di dalam Pasal 57. Kelemahan kedua, tidak diakomodirnya pembebanan pertanggungjawaban pidana terhadap korporasi yang menaungi televisi yang telah menayangkan siaran yang memicu kriminalitas anak. Kelemahan ketiga, terletak pada perumusan sanksi pidana yang hanya berupa pidana maksimal, tanpa adanya norma pidana minimal, sedemikian sehingga norma tersebut sangat rentan untuk disalah-gunakan oleh pihak tertentu, untuk menjatuhkan pidana dengan pidana yang serendah-rendahnya. Ketiga kelemahan tersebut, sangat potensil menimbulkan ketidak-pastian hukum dan ketidak-adilan serta berkontribusi secara nyata terhadap pelemahan penegakan hukum terhadap tindak-tindak pidana penyiaran. 
2.Kebijakan Hukum Pidana yang Sebaiknya Dinormakan di Dalam Undang-Undang Penyiaran di Masa Depan

Berdasarkan kesimpulan pada bagian terdahulu, kiranya dapat dijelaskan jawaban terhadap pertanyaan penelitian yang kedua, yakni "kebijakan hukum pidana yang bagaimana yang sebaiknya dinormakan terhadap pelaku tindak pidana pelanggaran isi siaran, di dalam Undang-Undang Penyiaran di masa depan?”.

Jawaban dimaksud tentu saja ditujukan agar norma ketentuan pidana pelanggaran isi siaran televisi, memenuhi asas kepastian hukum, keadilan dan kemanfaatan hukum, sedemikian sehingga dapat menangkal ditayangkannya siaran-siaran yang dapat memicu lahirnya kriminalitas anak akibat tayangan televisi.

Untuk maksud di atas, maka harus dilakukan dengan perubahan, perbaikan, dan atau penyempurnaan kelemahan ketentuan Undang-Undang Penyiaran, khususnya yang mengatur mengenai kejelasan dan ketegasan unsur-unsur tindak pidana penyiaran, pembebanan pertanggungjawaban pidana terhadap korporasi yang menjadi pemilik stasiun televisi yang menayangkan siaran yang berpotensi menimbulkan kriminalitas anak, dan penerapan norma sanksi pidana minimal di samping pidana maksimal yang telah berlaku saat ini.

Pertama, Pasal 57 Undang-Undang Penyiaran harus direvisi dengan memperjelas dan mempertegas maksud, batasan atau kriteria, atau dalam keadaan yang bagaimana sebuah tayangan disebut bersifat fitnah, menghasut, menyesatkan dan/atau bohong, menonjolkan unsur kekerasan, cabul, perjudian, penyalah-gunaan narkotika dan obat terlarang, atau mempertentangkan suku, agama, ras, dan antar golongan, serta tayangan yang memperolokkan, merendahkan, melecehkan dan/atau mengabaikan nilai-nilai agama, martabat manusia Indonesia, atau merusak hubungan internasional.

Kedua, mengingat bahwa stasiun televisi adalah sebuah organisasi modern yang canggih, dan penayangan sebuah siaran, merupakan keputusan yang dibuat secara resmi dan berjenjang, maka terhadap stasiun televisi yang telah menayangkan siaran yang dapat memicu lahirnya kriminalitas anak, sudah seharusnya pemidanaan tidak sekedar hanya dapat dijatuhkan kepada pelaku pada level pelaksana, melainkan harus mampu menjerat jajaran pimpinan perusahaan televisi. Lebih dari pada itu, karena keputusan penayangan siaran merupakan sebuah keputusan korporasi, maka kesalahan pimpinan perusahaan televisi menyiarkan tayangan yang melanggar ketentuan isi siaran dimaksud, harus dapat dibebankan menjadi pertanggungjawaban pidana korporasi. Untuk maksud tersebut, maka 
di dalam Undang-Undang Penyiaran, harus ditegaskan bahwa unsur "setiap orang" adalah termasuk korporasi, dan dirumuskan norma pertanggungjawaban korporasinya.

Ketiga, Undang-Undang Penyiaran harus memuat ketentuan tentang pidana minimum yang harus dijatuhkan kepada pelaku pidana penyiaran. Sebagai missal, pidana paling singkat yang dapat dijatuhkan kepada pelaku perbuatan pidana perbuatan pidana menayangkan isi siaran yang dapat memicu kriminalitas anak, adalah 1 (satu) tahun.

Dengan adanya pengaturan mengenai sanksi pidana minimal tersebut, akan diperoleh kepastian hukum dimana pada setiap terjadinya perbuatan pidana menayangkan siaran yang tidak mendidik dan merangsang tumbuhnya kriminalitas anak, maka pelakunya pasti dihukum setidaknya 1 (satu) tahun.

Formulasi sanksi pidana yang mengatur pidana mimimun dan maksimum tersebut akan menciptakan kepastian dalam penegakan hukum antara lain berupa efek penjeraan baik bagi pelaku maupun orang lain agar tidak melakukan perbuatan pidana yang sama.

\section{E. Kesimpulan}

1. Perumusan norma hukum tentang penayangan siaran pertelevisian yang dapat menyebabkan terjadinya kriminalitas anak, dapat dirujuk pada Pasal 57 UndangUndang Penyiaran. Norma ketentuan pidana tersebut tidak dapat dijadikan sarana hukum yang efektif untuk menangkal munculnya tayangan televisi yang berdampak pada lahirnya kriminalitas anak, karena perumusannya mengandung sejumlah kelemahan. Kelemahan pertama, perumusan unsur-unsur tindak pidana tidak dirumuskan secara jelas dan tegas. Kelemahan kedua, tidak diakomodirnya pembebanan pertanggungjawaban pidana terhadap korporasi yang menaungi televisi yang telah menayangkan siaran yang memicu kriminalitas anak. Kelemahan ketiga, perumusan sanksi pidana hanya berupa pidana maksimal, tanpa adanya norma pidana minimal, Ketiga kelemahan tersebut, sangat potensil menimbulkan ketidak-adilan serta berkontribusi secara nyata terhadap pelemahan penegakan hukum terhadap tindak-tindak pidana penyiaran.

2. Norma kebijakan hukum pidana yang sebaiknya dinormakan terhadap pelaku tindak pidana pelanggaran isi siaran, di dalam Undang-Undang Penyiaran di masa depan adalah norma yang memuat kejelasan dan ketegasan unsur-unsur tindak pidana penyiaran, pembebanan pertanggungjawaban pidana terhadap korporasi yang menjadi pemilik stasiun televisi yang menayangkan siaran yang berpotensi 
menimbulkan kriminalitas anak, dan norma sanksi pidana minimal di samping pidana maksimal yang telah berlaku saat ini.

\section{F. Rekomendasi}

1. Agar norma ketentuan pidana pelanggaran isi siaran televisi, dapat memenuhi asas kepastian hukum, keadilan dan kemanfaatan hukum, sedemikian sehingga mampu menangkal ditayangkannya siaran-siaran yang dapat memicu lahirnya kriminalitas anak akibat tayangan televisi, maka harus dilakukan:

a. Revisi Pasal 57 Undang-Undang Penyiaran dengan memperjelas dan mempertegas maksud, batasan atau kriteria, atau dalam keadaan yang bagaimana sebuah tayangan disebut melanggar isi siaran yang dapat memicu lahirnya kriminalitas anak;

b. Merumuskan pemidanaan yang tidak sekedar hanya dapat dijatuhkan kepada pelaku pada level pelaksana, melainkan harus mampu menjerat jajaran pimpinan perusahaan televisi. Kesalahan pimpinan perusahaan dimaksud, dirumuskan sebagai norma dalam pertanggungjawaban pidana korporasi.

c. Merumuskan ketentuan tentang pidana minimum yang harus dijatuhkan kepada pelaku pidana penyiaran, umpamanya pidana paling singkat yang dapat dijatuhkan kepada pelaku perbuatan pidana perbuatan pidana menayangkan isi siaran yang dapat memicu kriminalitas anak, adalah 1 (satu) tahun.

2. Agar konsepsi kebijakan hukum pidana yang diajukan benra-benar dapat diwujudkan demi menangkal dampak buruk tayangan televisi terhadap kriminalitas anak, maka Undang-Undang Penyiaran harus segera direvisi

\section{G. Daftar Pustaka}

Satjipto Raharjo, Ilmu Hukum, Citra Aditya Bhakti, Bandung, 1996

Barda Nawawi Arief, Bunga Rampai Kebijakan Hukum Pidana, Citra Aditya Bakti, Bandung, 2002

Nyoman, Sarikat Putra Jaya, Kapita Selekta Hukum Pidana, Badan Penerbit Undip, Semarang, 2005

Muladi, Kapita Selekta Sistem Peradilan Pidana, BP. Universitas Diponegoro, Semarang, 2002

Sudarto, Kapita Selekta Hukum Pidana, Alumni Bandung, 1981 
Mardjono Reksodiputro, Hak Asasi Manusia Dalam Sistem Peradilan Pidana, Kumpulan Karangan Buku Ketiga, Pusat Pelayanan Keadilan dan Pengabdian Hukum (d/h Lembaga Kriminologi Universitas Indonesia, Jakarta,

Siswantoro Sunarso, Penegakan Hukum Psikotropika Dalam Kajian Sosiologi Hukum, Rajawali Pers, Jakarta, 2004,

Muladi dan Barda Nawawi Arief, Teori-teori dan Kebijakan Pidana, Cet. Ketiga, Alumni, Bandung.2005

Littlejohn,Stephen W. \& Foss, Karen A., Theories of Human Communication, $8^{\text {th }}$ edition, Thomson Wadsworth, USA, 2005.

Muhammad Iksan, "Peran Media Massa Dalam Pembentukan Karakter", Makalah, FKIP Universitas Samawa Sumbawa Besar, 2010

Zubaedi, Desain Pendidikan Karakter: Konsepsi dan Aplikasinya dalam Lembaga Pendidikan, Kencana, Jakarta, 2011

Naina Akhmadsyah, M Alwi Dahlan, dkk (2008). Manusia Komunikasi Komunikasi Manusia, PT. Kompas Media Nusantara, Jakarta, 2008

Tim Pakar Jati Diri Bangsa, Pendidikan Karakter di Sekolah, Dari Gagasan ke Tindakan, Elex Media Komputindo, Jakarta, 2011. 